Supporting Information for

\title{
Multicore Ferrocene Derivative as a Highly Soluble Cathode Material for Nonaqueous Redox Flow Batteries
}

Hui Chen ${ }^{1}$, Zhihui Niu ${ }^{2}$, Jing Ye ${ }^{3}$, Changkun Zhang ${ }^{1}$, Xiaohong Zhang ${ }^{1}$, Yu Zhao*1

1 Institute of Functional Nano and Soft Materials (FUNSOM), Jiangsu Key Laboratory for Carbon-Based Functional Materials and Devices, Soochow University, 199 Ren'ai Road, Suzhou, Jiangsu 215123, P. R. China

2 School of Physics and Optoelectronic Engineering Shandong University of Technology, Zibo, Shandong 250049, P. R. China

${ }^{3}$ Analytical and Testing Center, Soochow University, 199 Ren'ai Road, Suzhou, Jiangsu 215123, P. R. China

* Author to whom should be addressed: jingye@suda.edu.cn (J.Y.), yuzhao@,suda.edu.cn (Y.Z.) 


\section{Experimental details}

\section{Materials}

All dry solvents were stored in sealed flask with suitable molecular sieves after distillation. All chemicals were used as received without further purification. Ferrocene (Fc, 98\%), phosphoric anhydride, phosphoric acid, methyl levulinate, Lithium aluminum hydride solution, Sodium hydride, 1-bromo-2-methoxyethane (98\%), sodium sulfate $\left(\mathrm{Na}_{2} \mathrm{SO}_{4}, 99 \%\right)$, sodium chloride $(\mathrm{NaCl}, 99.99 \%)$, bis(trifluoromethane) sulfonimide lithium salt (LiTFSI, 99.95\%) and Tetrabutylammonium Tetrafluoroborate $\left(\mathrm{TBABF}_{4}, 98 \%\right)$ were purchased from Sigma-Aldrich. Methanol (MeOH, 99.9\%) and Tetrahydrofuran (THF, 99.85\%) were purchased from Acros. Deionized water after deoxidization was used for all experiments. ${ }^{1} \mathrm{H}$ NMR and ${ }^{13} \mathrm{C}$ NMR spectra were recorded on a BrukerAvance 600 spectrometer, and the chemical shifts are reported as parts per million from TMS $(\delta)$. Mass spectra were acquired on HRMS (Bruker solanX 70 FT-MS).

\section{Synthesis of 4,4-diphenylpentanoic acid methyl ester (DFE)}

Polyphosphoric acid (PPA) was prepared by slowly adding phosphoric anhydride (12.5 g) to $85 \%$ phosphoric acid (12.5 g), followed by warming on the steam bath, with stirring, to obtain a solution. Methanol (14 ml) was added dropwise, with stirring, to the cooled acid and $15 \mathrm{ml}$ of cyclohexane contained in a three-necked flask equipped with a constant-rate addition funnel, condenser, stirrer, thermometer, and nitrogen inlet, keeping the temperature below $60^{\circ} \mathrm{C}$. Ferrocene $(9.3 \mathrm{~g}, 0.05 \mathrm{~mol})$ was introduced into the flask all at once and the stirred mixture heated in an oil bath maintained at $98-100^{\circ} \mathrm{C}$ throughout the reaction. Methyl levulinate $(9.75 \mathrm{~g}, 0.075 \mathrm{~mol})$ was added dropwise with vigorous stirring during $24 \mathrm{~h}$; ca. 0.02 mol was added during the first $2 \mathrm{~h}$ and the remainder at a constant rate until all added; temperature $76-78^{\circ} \mathrm{C}$ within the mixture throughout the reaction. After cooling to $25^{\circ} \mathrm{C}$, the mixture was stirred with $50 \mathrm{ml}$ each of water and benzene. The deep-orange upper layer was separated from the dark-green lower layer which was extracted twice with benzene. The combined organic solutions were washed successively with brine and the organic phase was dried over $\mathrm{Na}_{2} \mathrm{SO}_{4}$. After filtration and removal of the solvents under reduced pressure, the residue was purified by flash chromatography (N-hexane/Ethyl acetate, 11:1) to afford compound MFP (8.46 g, 71\%) as a red-brown oil. ${ }^{1} \mathrm{H}$ NMR (600 MHz, cdcl $) \delta 4.11$ (s, 16H, Cp-Cp’e), 4.00 (s, 2H, Cp'e), 3.64 (s, 3H, 
$\left.\mathrm{CH}_{3} \mathrm{O}\right), 2.28\left(\mathrm{~s}, 2 \mathrm{H}, \mathrm{CH}_{2}\right), 2.18\left(\mathrm{~s}, 2 \mathrm{H}, \mathrm{CH}_{2}\right), 1.56\left(\mathrm{~s}, 3 \mathrm{H}, \mathrm{CH}_{3} \mathrm{C}\right) ;{ }^{13} \mathrm{C} \mathrm{NMR}\left(600 \mathrm{MHz}, \mathrm{CDCl}_{3}\right): \delta$ $174.66(\mathrm{C}=\mathrm{O}), 99.73$ (Fc-C-Fc), 68.62 (Cp), 66.91, 66.34 (Cp'e), 66.74 (Cp'e-C), 51.55 (CH3O), 38.32 $\left(\mathrm{CH}_{2}\right)$, $30.13\left(\mathrm{CH}_{2}\right)$, $24.26\left(\mathrm{CH}_{3}\right)$; HRMS (m/z): Calcd for $\mathrm{C}_{26} \mathrm{H}_{28} \mathrm{Fe}_{2} \mathrm{O}_{2}$ : 484.078322. Found: 484.078278 .

\section{Synthesis of 4,4-diferrocenylpentan-1-ol (DFO)}

Powdered $\mathrm{LiAlH}_{4}(0.95 \mathrm{~g}, 25 \mathrm{mmol})$ was added to the ice-cooled solvent under nitrogen atmosphere. A solution of distilled DFE $(8.1 \mathrm{~g}, 16.7 \mathrm{mmol})$ in dry THF $(100 \mathrm{~mL})$ was placed in a dropping funnel and was added to the stirred ice-cooled suspension of the reductant dropwise. After the addition was completed, the reaction mixture was allowed to come to ambient temperature $(0.5 \mathrm{~h})$ and was heated with a water-bath to $40{ }^{\circ} \mathrm{C}$ for $8 \mathrm{~h}$. The progress of the reaction can be monitored by TLC. After the reaction was complete, it was dripped into ice-cooled water $(200 \mathrm{~mL})$ by inches in order to quench this reaction. Then, the aqueous phase was extracted with EA $(3 \times 200 \mathrm{~mL})$ and the organic phase was dried over $\mathrm{Na}_{2} \mathrm{SO}_{4}$. The solvent was evaporated in vacuo to yield dark-red solid $(6.94 \mathrm{~g}, 91 \%)$. Without further purification, its purity can meet the need of next reaction.

\section{Synthesis of 4,4-diferrocenyl-1-(2-Methoxy-ethoxy)-pentane (DFDE)}

To a solution of DFO $(6.85 \mathrm{~g}, 15 \mathrm{mmol})$ in dry THF $(120 \mathrm{~mL})$ was added Sodium hydride $(0.9 \mathrm{~g}, 22.5$ mmol) under nitrogen atmosphere. The reaction mixture was then stirred for $1 \mathrm{~h}$ at room temperature. Next, 1-bromo-2-methoxyethane would be added by dripping slowly at room temperature when the solution had become dark-green. The mixture was stirred at room temperature overnight. After the reaction monitored by TLC was completed, it was poured into ice-cooled water $(100 \mathrm{~mL})$ for redundant Sodium hydride consumed and extracted with EA $(3 \times 100 \mathrm{~mL})$. The combined organic layers were washed with brine $(20 \mathrm{~mL})$, dried over $\mathrm{Na}_{2} \mathrm{SO}_{4}$, and concentrated under the reduced pressure to give a dark-brown oil. Later, the dark-red syrup was purified by column chromatography (N-hexane/Ethyl acetate, 10:1) to afford compound $\mathbf{d}(1.75 \mathrm{~g}, 82 \%)$ as a red oil. ${ }^{1} \mathrm{H}$ NMR (400 MHz, $\left.\mathrm{CDCl}_{3}\right): \delta 4.03$ (s, 16H, Cp), 3.93 (s, 2H, Cp'e-C), 3.46 (s, 4H), 3.33 (d, J=6.8 Hz, 2H, $\left.\mathrm{CH}_{2}\right), 3.31$ (s, 3H, $\left.\mathrm{CH}_{3} \mathrm{O}\right), 1.83-$ $1.75\left(\mathrm{~m}, 2 \mathrm{H}, \mathrm{CH}_{2}\right), 1.51\left(\mathrm{~s}, 3 \mathrm{H}, \mathrm{CH}_{3} \mathrm{C}\right), 1.49\left(\mathrm{~s}, 2 \mathrm{H}, \mathrm{CH}_{2}\right) .{ }^{13} \mathrm{C} \mathrm{NMR}\left(400 \mathrm{MHz}, \mathrm{CDCl}_{3}\right): 100.88$ (Fc-C-Fc), 72.10 (Cp), 69.92, 68.85 (Cp'e), 66.84 (Cp'e-C), $59.13\left(\mathrm{CH}_{3} \mathrm{O}\right), 39.99\left(\mathrm{CH}_{2}\right), 36.02$ $\left(\mathrm{CH}_{2}-\mathrm{O}-\mathrm{CH}_{2}\right), 24,96\left(\mathrm{CH}_{2}\right), 24.47\left(\mathrm{CH}_{3}\right)$; HRMS (m/z): Calcd for $\mathrm{C}_{28} \mathrm{H}_{34} \mathrm{Fe}_{2} \mathrm{O}_{2}$ : 514.125281. Found: 514.125223. 


\section{Cyclic voltammetry (CV) studies}

Electrochemical measurements were conducted on the three-electrode system of electrochemical station (Gamry reference 3000), which was constituted by A glass carbon working electrode (Shanghai Chu Xi Industrial Co., Ltd.) with the diameter of $3 \mathrm{~mm}$, A platinum wire was served as the counter electrode (Jiangsu Shenzhou carbon product Co., Ltd) and a $\mathrm{Ag} / \mathrm{AgCl}$ reference electrodes (Shanghai Huachen Instrument Co., Ltd.). The cyclic voltammetry (CV) was tested on $5 \mathrm{mM}$ DMDF and $10 \mathrm{mM}$ $\mathrm{BFD}$ in $0.5 \mathrm{M} \mathrm{TBABF}_{4} \mathrm{ACN}$ with scanning rates from $50 \mathrm{mV} \mathrm{s}^{-1}$.

\section{RDE studies}

RDE measurements were operated via a rotating disk electrode (RRDE-3A, ALS Co. Ltd.), which included in a $\mathrm{Ag} / \mathrm{AgCl}$ electrode as the reference electrode, a platinum wire as the counter electrode and a three-electrode configuration with a glassy-carbon disk (3 $\mathrm{mm}$ in diameter) as the working electrode. RDE profiles were acquired under the different rotating speeds with a fixed sweeping rate of $10 \mathrm{mV} \mathrm{s}^{-1}$. The rotation speeds for the catholyte were 900, 1225, 1600, 2025, 2500, 3025 and $3600 \mathrm{rpm}$. $\eta$ used for the calculation of $k_{0}$ was $40,50,60,70$ and $80 \mathrm{mV}$.

Using the slopes of the linearly fitted Levich plots (Figure 5d) and the Levich equation (Equation 2), the diffusion coefficients $(D)$ of DFDE and $\mathrm{DFDE}^{+}$were calculated. Using the Koutecký-Levich equation (Equation 2), Koutecký-Levich plots (Figures $5 \mathrm{~b}$ and c) were obtained.

$$
\begin{gathered}
i_{L}=0.62 n F A D^{2 / 3} \omega^{1 / 2} v^{-1 / 6} C_{0} \\
\frac{1}{i}=\frac{1}{i_{k}}+\frac{1}{0.62 n F A D^{2 / 3} \omega^{1 / 2} v^{-1 / 6} C_{0}} \\
i_{0}=0.62 n F A k_{0} C_{0}
\end{gathered}
$$

Here, $n$ is the number of electrons transferred $(n=1), F$ is the Faraday constant $\left(F=96485 \mathrm{As} \mathrm{mol}^{-1}\right), A$ is the electrode area $\left(A=0.0707 \mathrm{~cm}^{2}\right)$, and $C_{0}$ is the concentration of the DFDE $\left(C_{0}=0.5 \mathrm{mM}\right)$.

\section{Determination of the solubility of (DFDE)}

To determine the solubility of DFDE in bare DME and ACN solvent, excess DFDE ( $0.2 \mathrm{~g}$ ) was separately added to the $2 \mathrm{ml} \mathrm{DME}$ and $2 \mathrm{ml} \mathrm{ACN}$, respectively. After stirring for sufficient time, the upper clear solution was transferred into a volumetric flask $(1 \mathrm{~mL})$ and vaporized in vacuum at room temperature. The remaining DFDE was weighed to be $1.18 \mathrm{~g}$ and $0.272 \mathrm{~g}$, respectively, corresponding to a molar concentration of $2.3 \mathrm{M}$ in DME and $0.53 \mathrm{M}$ in $\mathrm{ACN}$, respectively. 


\section{UV-vis spectroscopy}

For the UV-vis spectroscopy analysis, absorption spectra of the electrolytes in the positive electrode compartment (diluted in $\mathrm{MeCN}, 5 \% \mathrm{v} / \mathrm{v}$ ) were obtained using a UV-vis spectrometer (Agilent Technologies, Cary 5000) with an optical glass cuvette (Quartz; Hellma). Electrolytes containing 50 mM DFDE and $100 \mathrm{mM}$ BuPh in the supporting electrolyte of $0.5 \mathrm{M} \mathrm{TBABF}_{4}$ in $\mathrm{MeCN}$ were used.

\section{Static half-cell test}

A half-cell was assembled with two quartz shells (1 $\mathrm{mm}$ thick, $8 \mathrm{~mm}$ in diameter) and a NASICON-type $\mathrm{Li}_{1+\mathrm{x}+3 z} \mathrm{Al}_{x}(\mathrm{Ti}, \mathrm{Ge})_{2-\mathrm{x}} \mathrm{Si}_{3 \mathrm{z}} \mathrm{P}_{3-\mathrm{z}} \mathrm{O}_{12} \mathrm{Li}^{+}$- ion conducting membrane (LICGC® AG-01, Ohara Corp., Japan) sandwiched in between. The components were sealed together with Surlyn ${ }^{\circledR}$ resin (Solaronix Meltonix 1170-25). A Ti foil precasted with a Super P carbon/PVDF thin layer was used as the current collector for the cathode, and a piece of $\mathrm{Li}$ foil pressed onto the $\mathrm{Cu}$ foil was used as the anode. The electrolyte was injected into the quartz shell chamber through a small hole on the $\mathrm{Ti}$ or $\mathrm{Cu}$ foil. The electrolyte used at the anode was 1 M LiTFSI in DME, whereas the electrolyte used in the cathode was 0.1 M DFDE in DME containing $1 \mathrm{M}$ LiTFSI and $1 \mathrm{M}$ DFDE in DME containing $2.5 \mathrm{M}$ LiTFSI, respectively.

\section{Static full cell test}

The cell was assembled with a piece of Daramic $175^{\circledR}$ sandwiched between two quartz shells $(1 \mathrm{~mm}$ thick, $8 \mathrm{~mm}$ in diameter), graphite felts $(7 \mathrm{~mm}$ diameter and $1.5 \mathrm{~mm}$ thickness) and Ti foil pre-casted with a Super P carbon/PVDF thin layer. All cell tests were carried out at room temperature on a potentiostat (BT-2043, Arbin instruments).

\section{Calculation method}

The structure optimization was performed with Gaussian 09 software package [1], Data analysis and picture drawing were using Multiwfn [2] and VESTA, The structure optimization using the b3lyp as the functional, hybrid basis set was set with lanl2dz for Fe atom and 6-31g (d,p) for C, H, O atoms, respectively [1, 3-5]. Implicit solvent model of SMD were performed to account the solvation effect of acetonitrile using m062X functional. Electronic spin density was calculated using the non-restrictive open-shell method to eliminate the possibility of spin-polarized singlet state in the +1 and +2 valence 
states with guess $=$ mix to break the symmetry of frontier molecular orbitals.

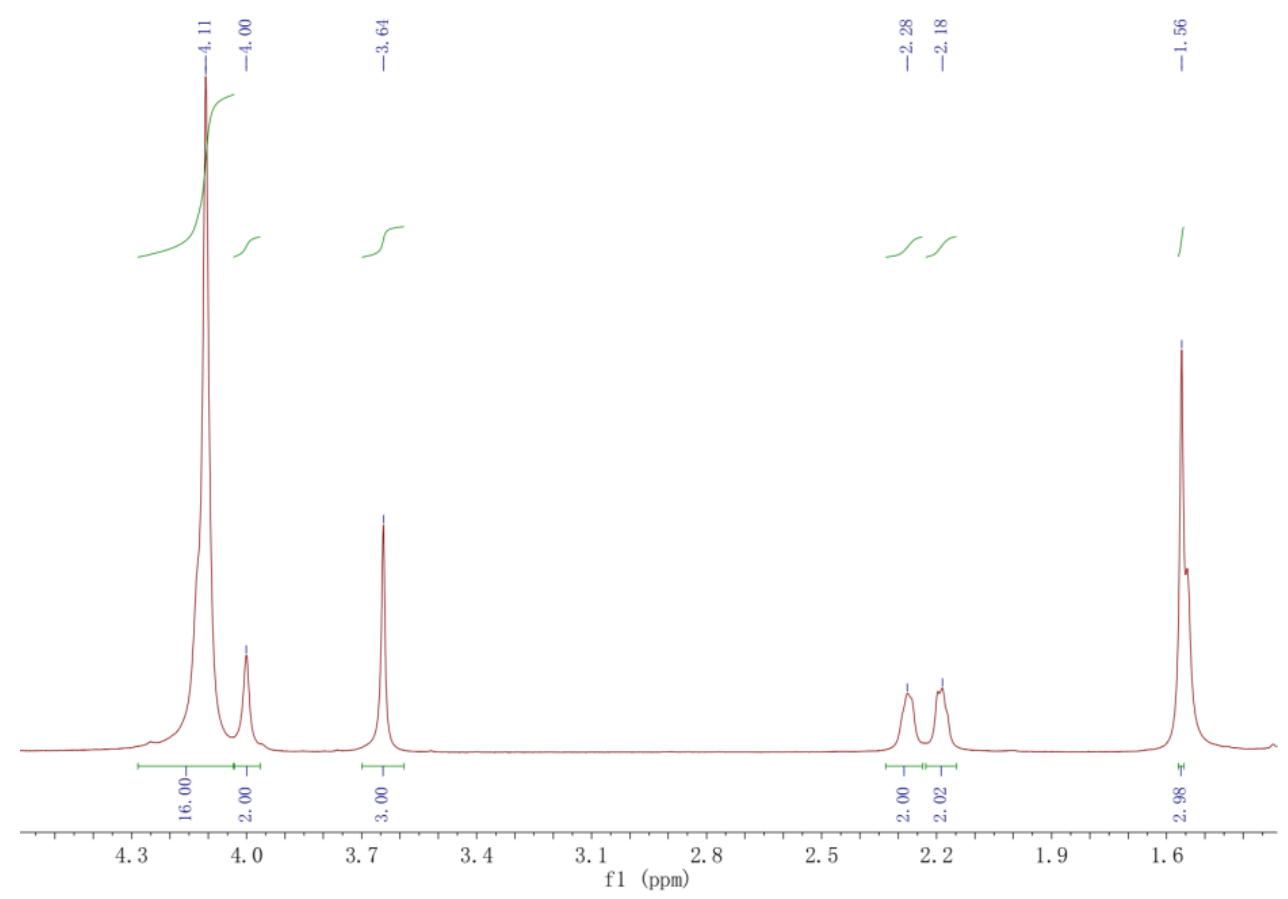

Figure S1. ${ }^{1} \mathrm{H}$ NMR spectra of DFE.

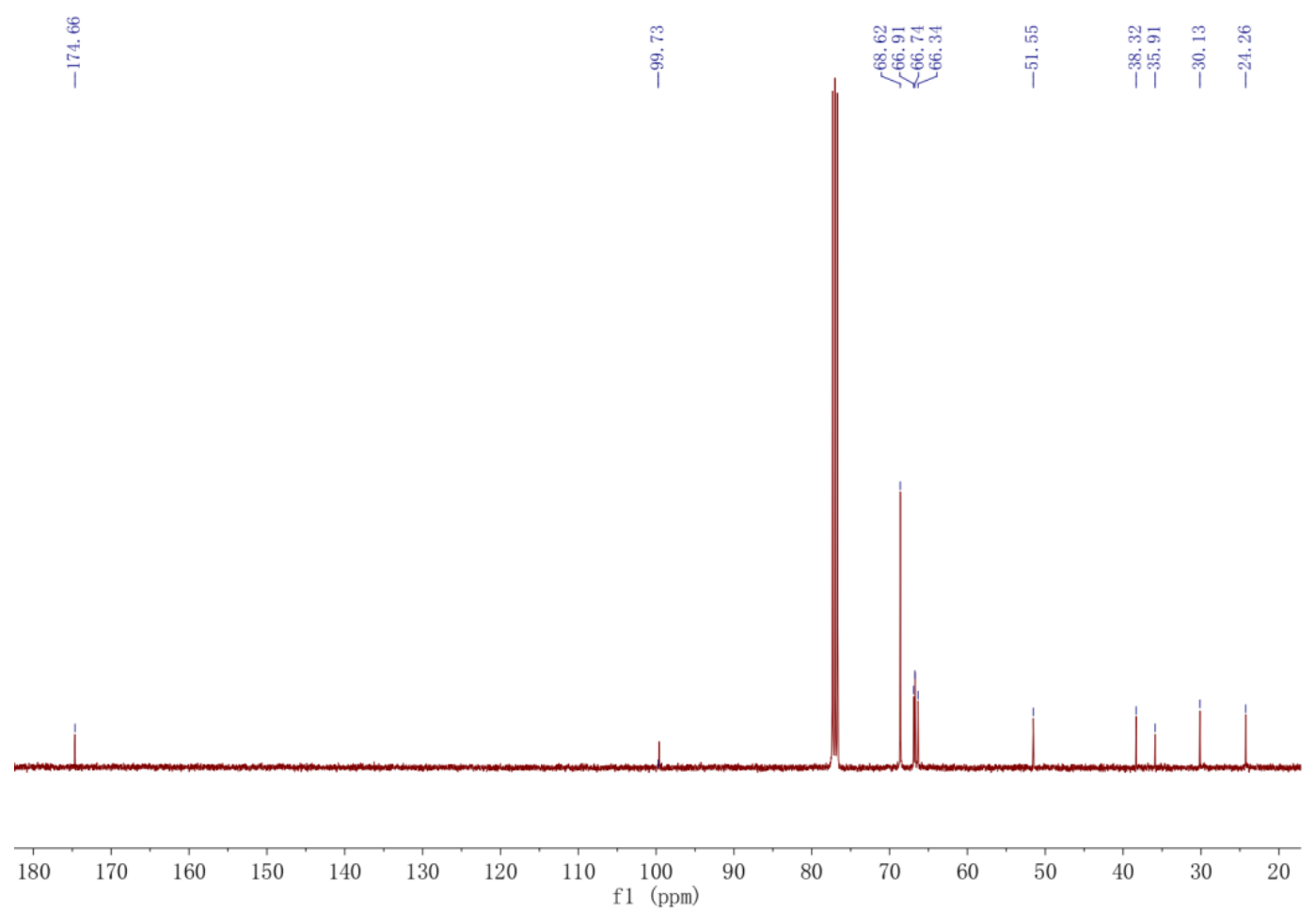

Figure S2. ${ }^{13} \mathrm{C}$ NMR spectra of DFE. 


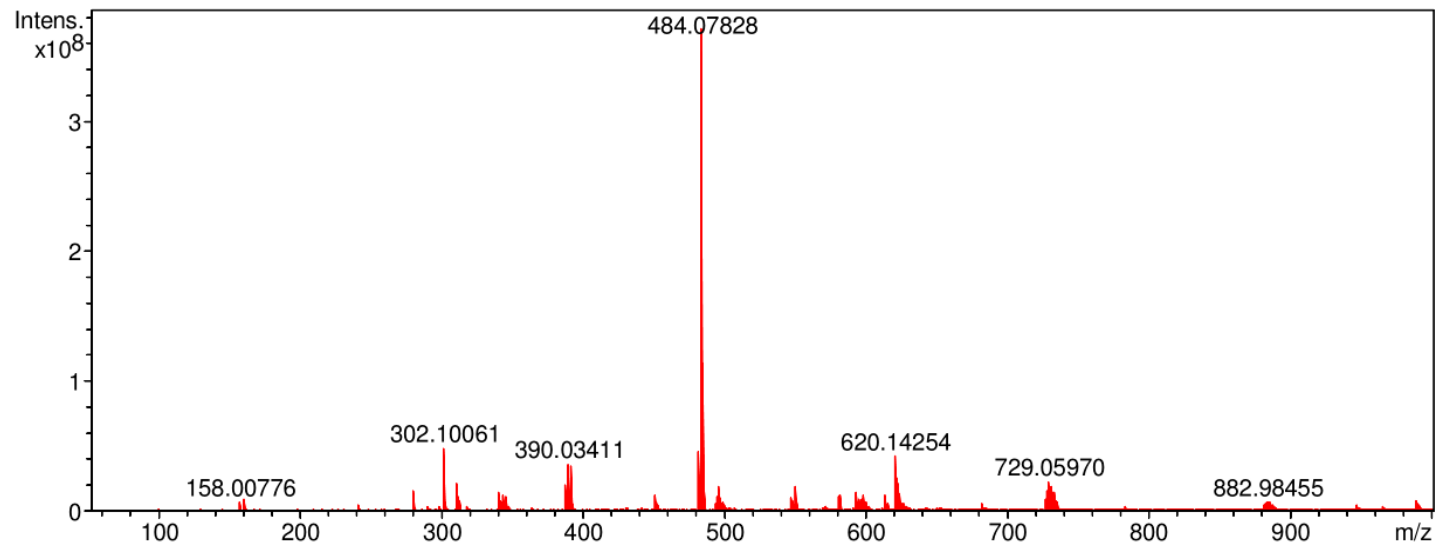

Figure S3. ESI-MS of DFE.

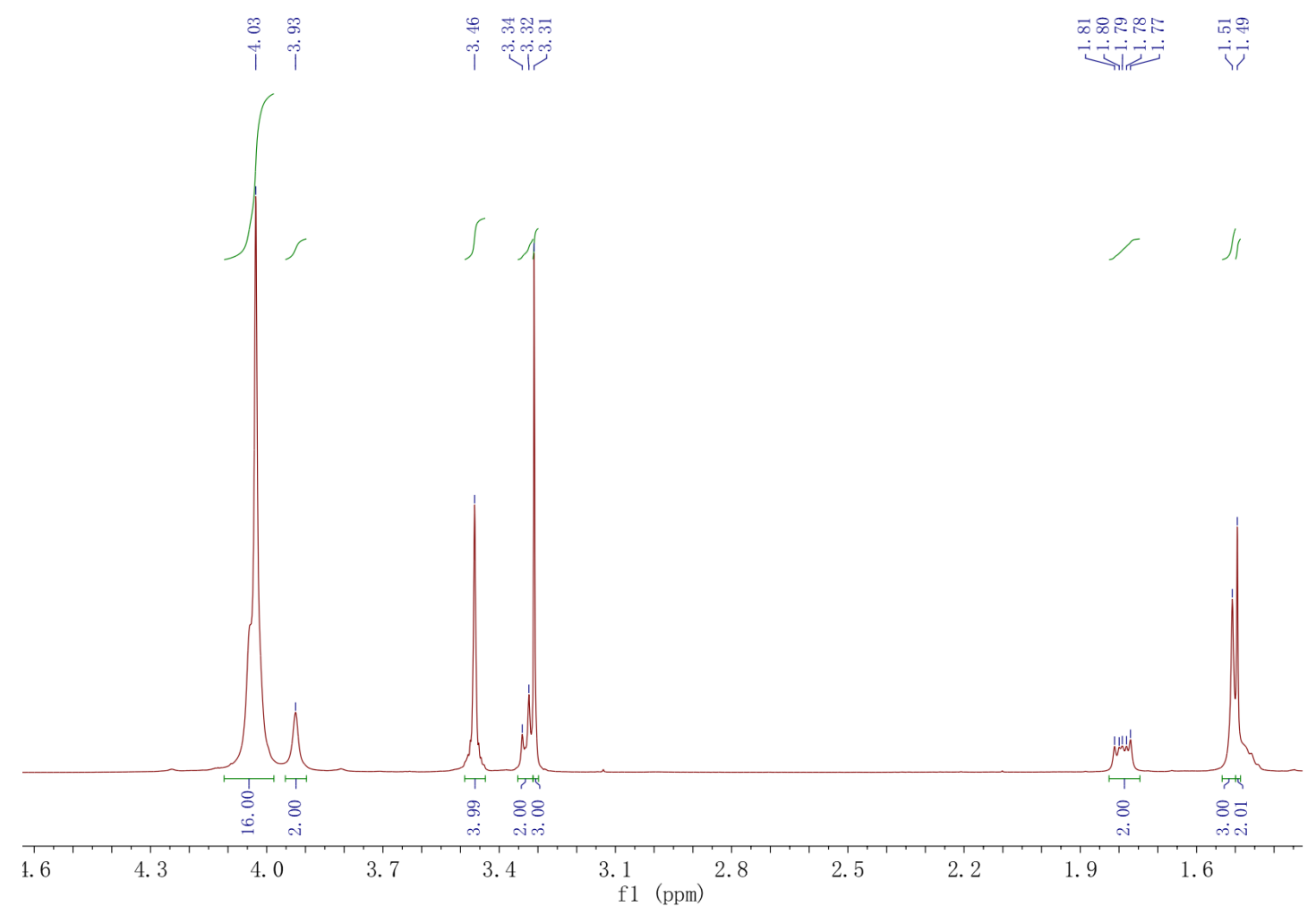

Figure S4. ${ }^{1} \mathrm{H}$ NMR spectra of DFDE. 


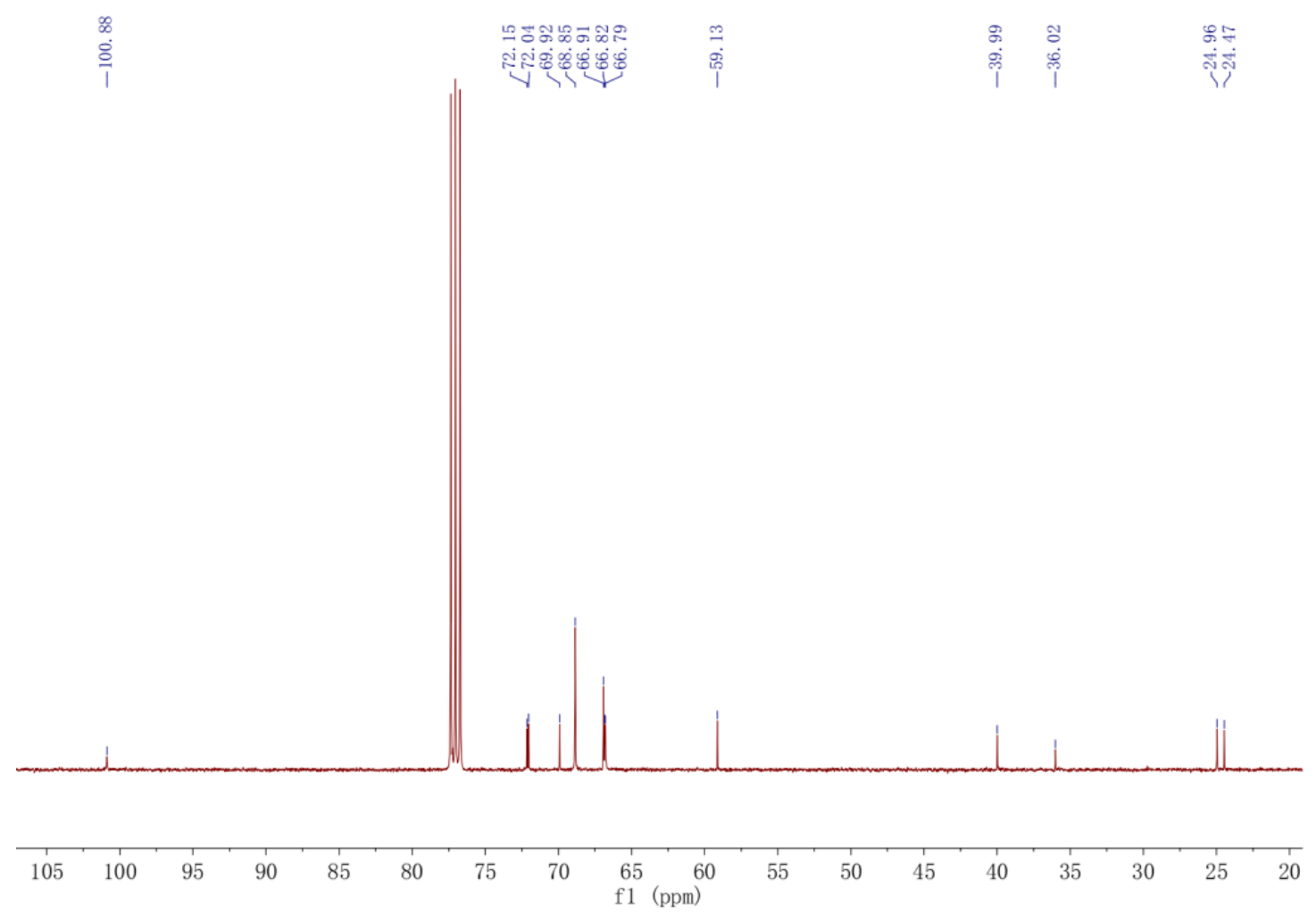

Figure S5. ${ }^{13} \mathrm{C}$ NMR spectra of DFDE.

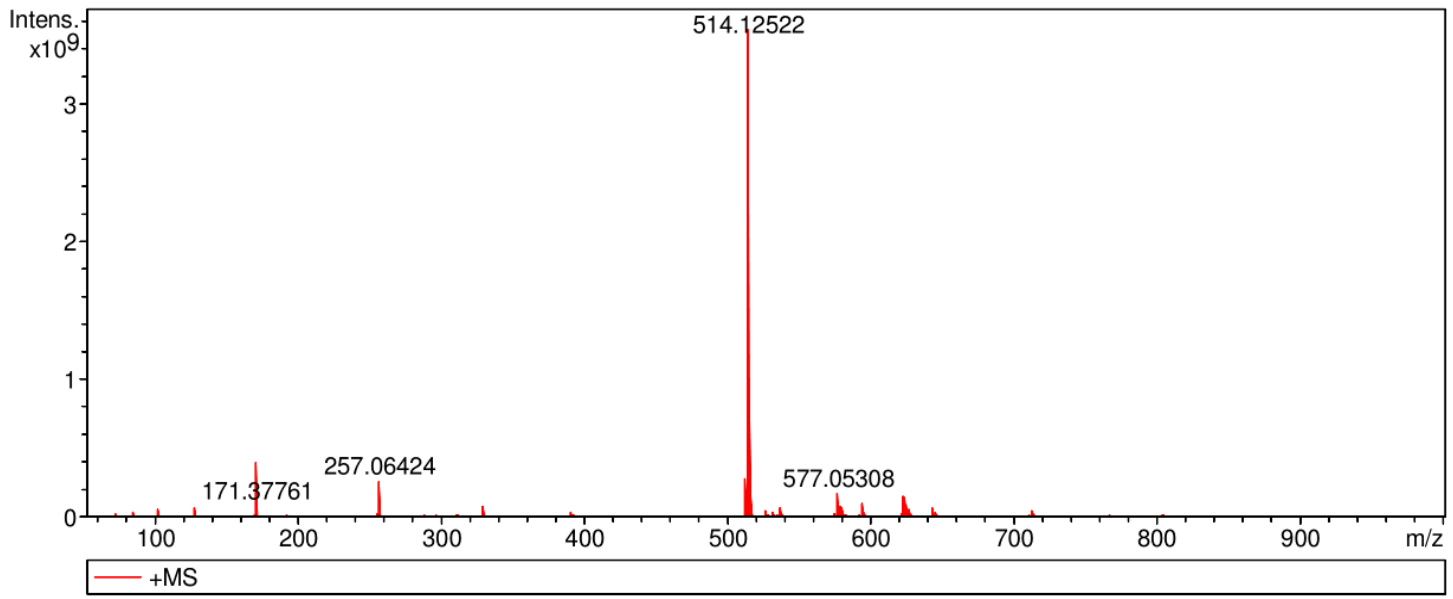

Figure. S6. ESI-MS of DFDE. 


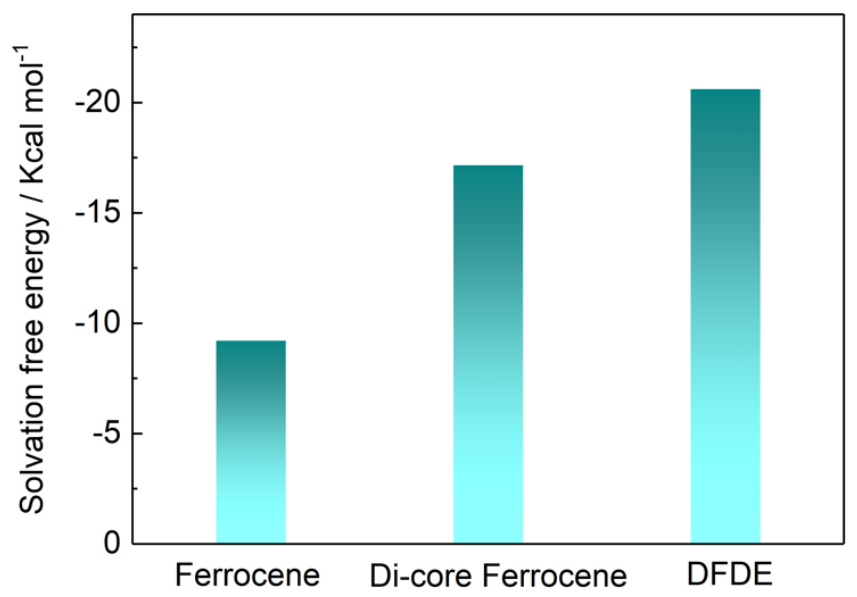

Figure S7. Calculated solvation free energy of Ferrocene, Di-core ferrocene and DFDE, respectively.

Table. S1. Summary of ferrocene-based redox species for NARFBs applications

\begin{tabular}{|c|c|c|c|c|c|}
\hline Molecule & $\begin{array}{l}\text { Number of } \\
\text { electrons }\end{array}$ & Electrolyte & $\begin{array}{c}\text { Solubility } \\
\text { (M) }\end{array}$ & $\begin{array}{l}\text { Redox potential V } \\
\quad\left(\text { vs. } \mathrm{Fc} / \mathrm{Fc}^{+}\right)\end{array}$ & Ref. \\
\hline & 1 & 1.2 M LiTFSI/EC/PC/EMC (4:1:5) & 0.04 & 0 & {$[6]$} \\
\hline & 1 & 1.2 M LiTFSI/EC/PC/EMC (4:1:5) & 0.85 & 0.2 & {$[6]$} \\
\hline & 1 & $\mathrm{EC} / \mathrm{PC} / \mathrm{EMC}(4: 1: 5)$ & 0.4 & $\sim 0.2$ & [7] \\
\hline $\mathrm{ClO}_{4}^{-}$ & 1 & $\mathrm{EC} / \mathrm{PC} / \mathrm{EMC}(4: 1: 5)$ & 0.63 & 0.15 & {$[7]$} \\
\hline & 1 & EC/PC/EMC (4:1:5) & 2.08 & NA & [7] \\
\hline & 1 & $\mathrm{EC} / \mathrm{PC} / \mathrm{EMC}(4: 1: 5)$ & 1.71 & 0.14 & {$[7]$} \\
\hline & 1 & $\mathrm{EC} / \mathrm{DEC}$ at $50^{\circ} \mathrm{C}$ & 3 & -0.05 & [8] \\
\hline cis & 1 & 1.0 $\mathrm{M} \mathrm{TEAPF}_{6} / \mathrm{CAN}$ & $<0.5$ & 0.18 & {$[9]$} \\
\hline
\end{tabular}



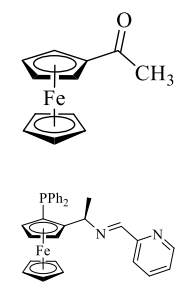

2

1.0 $\mathrm{M} \mathrm{LiPF}_{6} / \mathrm{EC} / \mathrm{PC} / \mathrm{EMC}(1: 1: 1)$

$\sim 0.6$

0.58

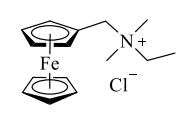

1

$\mathrm{H}_{2} \mathrm{O}$

$4 \quad 0.61 \mathrm{~V} v s$. SHE

[12]

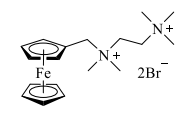

$1 \quad \mathrm{H}_{2} \mathrm{O}$

3.1

$0.61 \mathrm{~V} v s . \mathrm{SHE}$

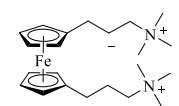

1

$\mathrm{H}_{2} \mathrm{O}$

$1.9 \quad 0.39 \mathrm{~V} v s . \mathrm{SHE}$

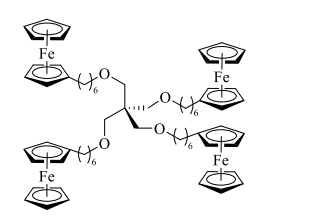

4

ACN/THF (4:1)

$>0.25$

$0.15 \mathrm{~V} v s$

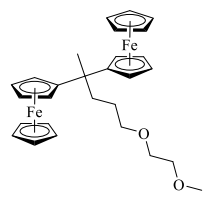

DME

2.3

0.08

This

2

CAN

0.53

0.12

work

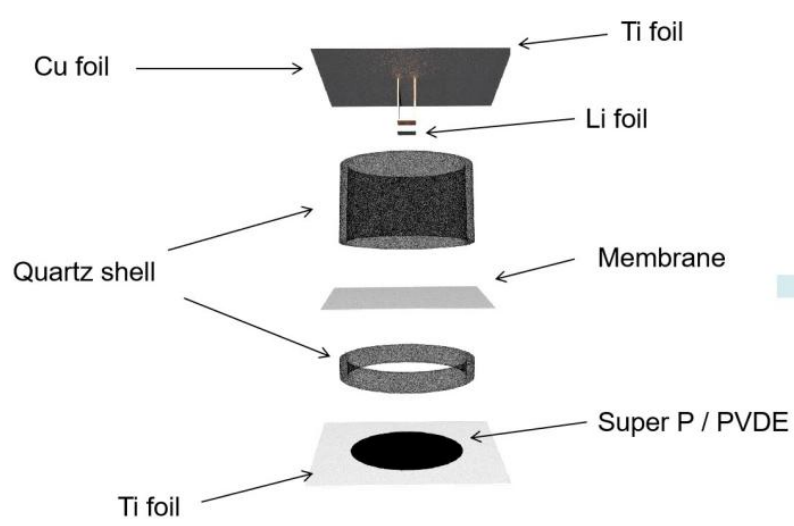

Figure. S8. Photo of the static half-cell device 

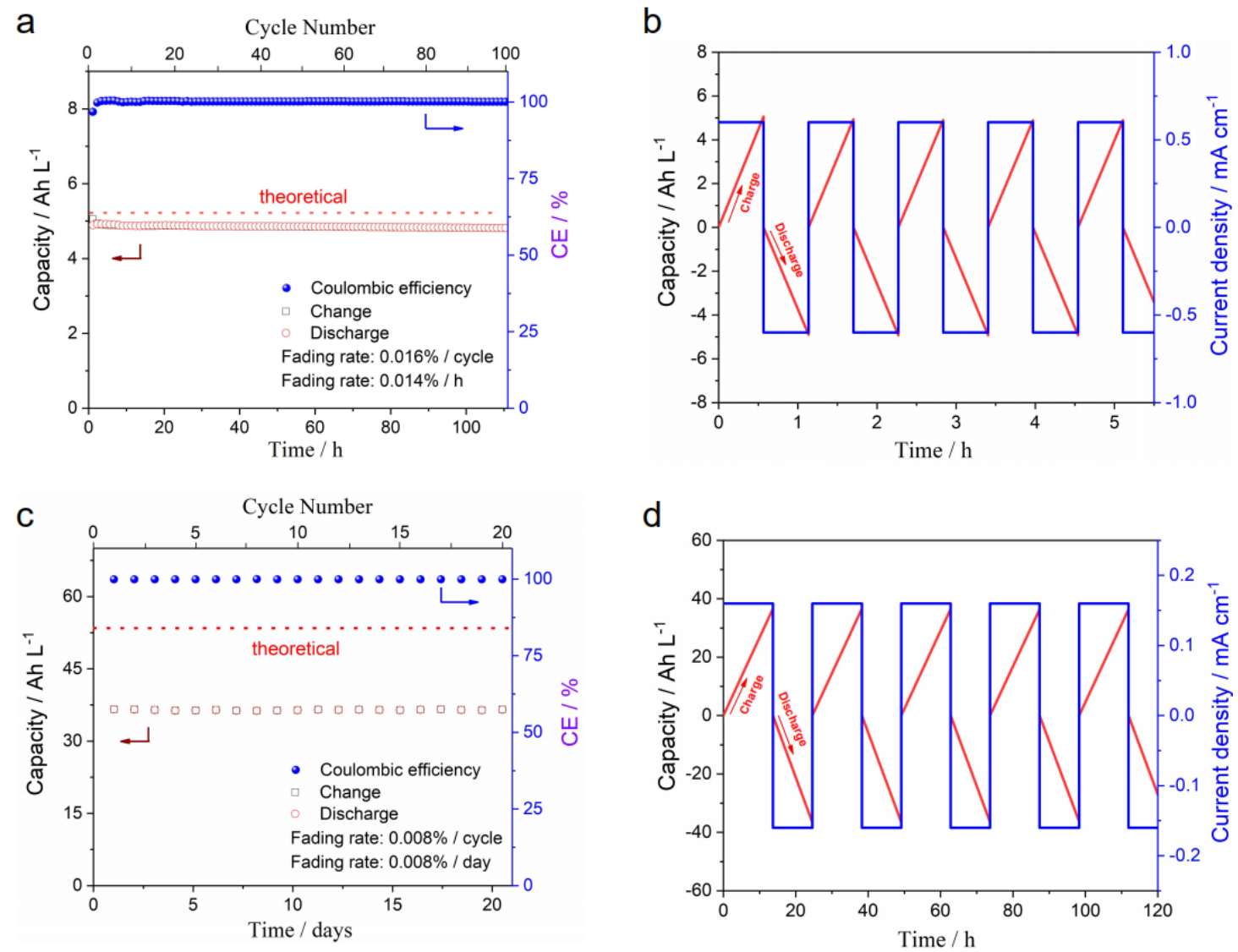

Figure. S9. Charge-discharge behaviors of DFDE $\mid \mathrm{Li}$ half-cell. Coulombic efficiency and charge-discharge capacities versus time and cycle number using the catholyte containing 0.1 M DFDE (a) and 1 M DFDE (c). Charge-discharge under galvanostatic conditions using the catholyte containing 0.1 M DFDE (b) and $1 \mathrm{M}$ DFDE (d).

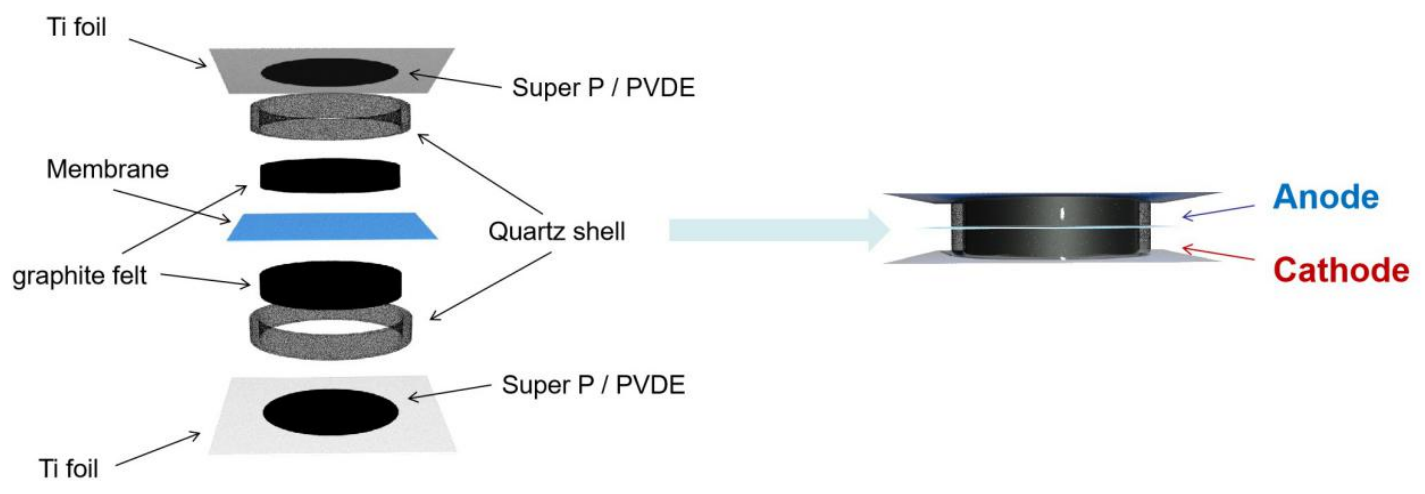

Figure. S10. Photo of the static full cell device. 


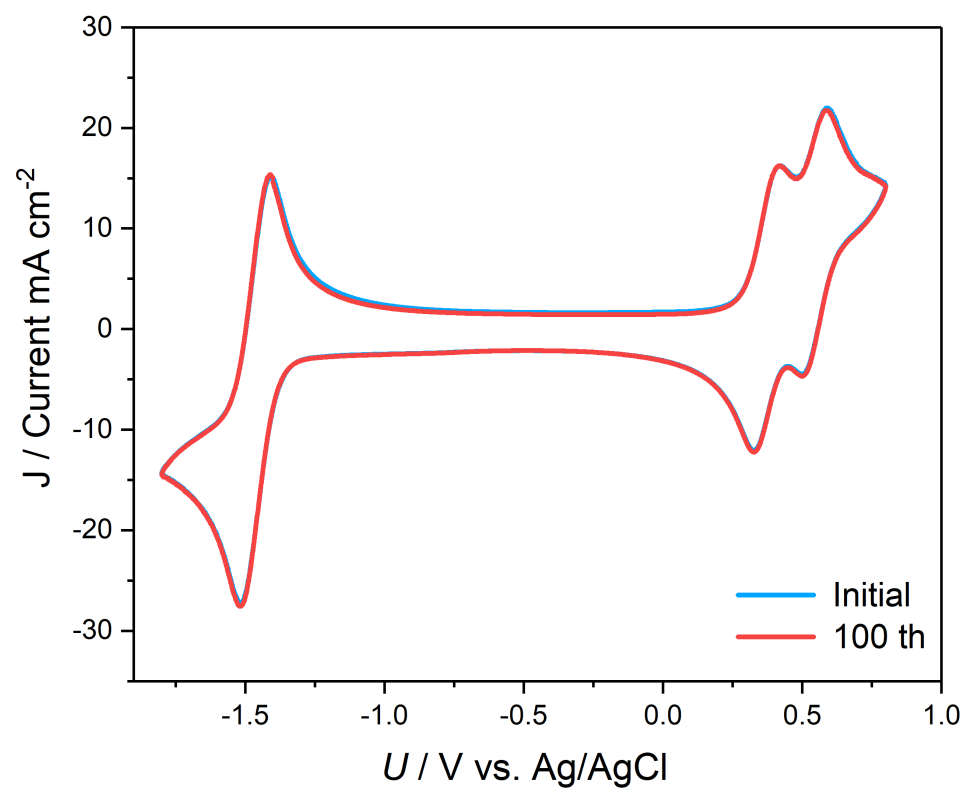

Figure S11. CV curves of DFDE and BuPh electrolyte at $50 \mathrm{mV} \mathrm{s}^{-1}$.

a

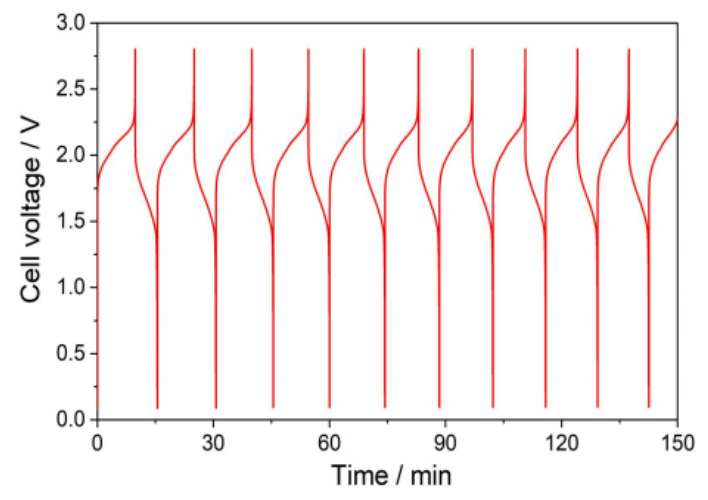

b

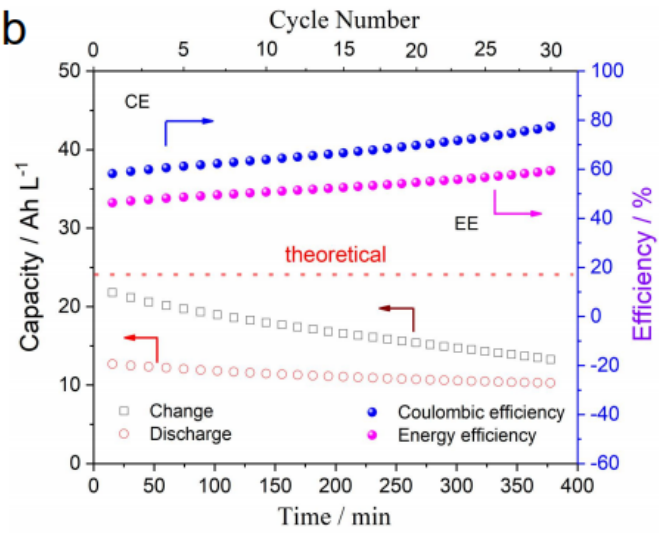

Figure S12. Charge-discharge behaviors of DFDE | BuPh cell. (a) Representative first ten charge/discharge voltage profiles over time of the symmetric static cell. (b) Coulombic efficiency and charge-discharge capacities versus time and cycle number. The electrolyte used in the symmetric cell is an acetonitrile solution containing 0.45 M DFDE, 0.9 M BuPh and 1.2 M TBABF 4 . The current density is $20 \mathrm{~mA} \mathrm{~cm}^{-2}$. 

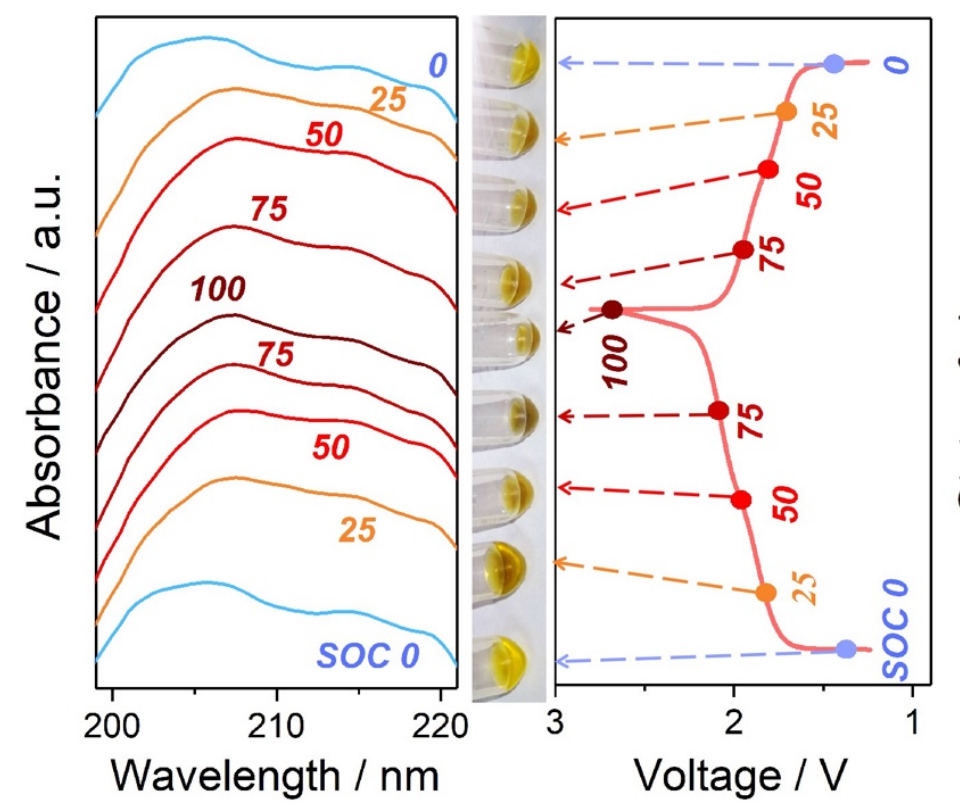

0
0
0
$\frac{c}{0}$
$\frac{1}{0}$
$\frac{1}{0}$
$\frac{1}{0}$
0
0

Figure S13. UV-vis spectra corresponding to the colors of the BFD at the given SOCs.

\section{Reference}

(1) Becke, A. D. Density-functional thermochemistry. III. The role of exact exchange The Journal of Chemical Physics 1993, 98, 5648-5652.

(2) Lu, T.; Chen, F. Multiwfn: a multifunctional wavefunction analyzer $J$ Comput Chem 2012, 33, $580-592$.

(3) Dill, J. D.; Pople, J. A. Self-consistent molecular orbital methods. XV. Extended Gaussian-type basis sets for lithium, beryllium, and boron The Journal of Chemical Physics 1975, 62, 2921-2923.

(4) Francl, M. M.; Pietro, W. J.; Hehre, W. J.; Binkley, J. S.; Gordon, M. S.; DeFrees, D. J.; Pople, J. A. Self-consistent molecular orbital methods. XXIII. A polarization-type basis set for second-row elements The Journal of Chemical Physics 1982, 77, 3654-3665.

(5) Hehre, W. J.; Ditchfield, R.; Pople, J. A. Self-Consistent Molecular Orbital Methods. XII. Further Extensions of Gaussian-Type Basis Sets for Use in Molecular Orbital Studies of Organic Molecules 
The Journal of Chemical Physics 1972, 56, 2257-2261.

(6) Wei, X.; Cosimbescu, L.; Xu, W.; Hu, J. Z.; Vijayakumar, M.; Feng, J.; Hu, M. Y.; Deng, X.; Xiao, J.; Liu, J.; Sprenkle, V.; Wang, W. Towards High-Performance Nonaqueous Redox Flow Electrolyte Via Ionic Modification of Active Species Advanced Energy Materials 2015, 5, 1400678.

(7) Cosimbescu, L.; Wei, X.; Vijayakumar, M.; Xu, W.; Helm, M. L.; Burton, S. D.; Sorensen, C. M.; Liu, J.; Sprenkle, V.; Wang, W. Anion-Tunable Properties and Electrochemical Performance of Functionalized Ferrocene Compounds Sci Rep 2015, 5, 14117.

(8) Cong, G.; Zhou, Y.; Li, Z.; Lu, Y.-C. A Highly Concentrated Catholyte Enabled by a Low-Melting-Point Ferrocene Derivative ACS Energy Letters 2017, 2, 869-875.

(9) Hwang, B.; Park, M. S.; Kim, K. Ferrocene and cobaltocene derivatives for non-aqueous redox flow batteries ChemSusChem 2015, 8, 310-314.

(10) Kim, H.-s.; Yoon, T.; Kim, Y.; Hwang, S.; Ryu, J. H.; Oh, S. M. Increase of both solubility and working voltage by acetyl substitution on ferrocene for non-aqueous flow battery Electrochemistry Communications 2016, 69, 72-75.

(11) Xie, C.; Xu, W.; Zhang, H.; Hu, X.; Li, X. A multi-electron transfer ferrocene derivative positive redox moiety with improved solubility and potential Chem Commun (Camb) 2018, 54, 8419-8422.

(12) DeBruler, C.; Hu, B.; Moss, J.; Liu, X.; Luo, J.; Sun, Y.; Liu, T. L. Designer Two-Electron Storage Viologen Anolyte Materials for Neutral Aqueous Organic Redox Flow Batteries Chem 2017, 3, 961-978.

(13) Hu, B.; DeBruler, C.; Rhodes, Z.; Liu, T. L. Long-Cycling Aqueous Organic Redox Flow Battery (AORFB) toward Sustainable and Safe Energy Storage $J$ Am Chem Soc 2017, 139, 1207-1214.

(14) Milton, M.; Cheng, Q.; Yang, Y.; Nuckolls, C.; Hernandez Sanchez, R.; Sisto, T. J. Molecular 
Materials for Nonaqueous Flow Batteries with a High Coulombic Efficiency and Stable Cycling Nano Lett 2017, 17, 7859-7863. 